\title{
mEiEa
}

\section{Kahoot!: A Tool in the Effective Teacher's Toolbox}

\author{
Eric Holt \\ Belmont University \\ Amy Bryson Smith \\ Belmont University \\ This paper was presented at the 2019 International Summit of the \\ Music \& Entertainment Industry Educators Association
}

March 21-23, 2019

https://doi.org/10.25101/19.26

\section{Abstract}

The desired outcome for instructors who seek to competently teach students can often be summarized in two words: student success. Although, the input necessary to achieve student success varies dramatically with each class, one constant is the effective teacher. Defining what an "effective" teacher is proves to be difficult because for every class the "effective" teacher is different.

As of late, whether you agree or not, effective teachers are often described as enterprising and entertaining. Enterprising - being marked by imagination and initiative; and entertaining - being agreeably diverting or providing amusement. The debate about creating an entertaining and/ or enterprising classroom certainly exists. But, no matter who wins the debate, it is clear that students of all ages are being entertained in every other facet of their life, and even if they do not expect it in their classroom, they surely appreciate and often respond to it!

Kahoot! is a free game-based learning platform for any subject and for all ages. It is designed to make learning fun. Students are able to join from any device, such as their smart phone, tablet, or computer. Whether utilizing one of the many existing Kahoot! games or creating your own, Kahoot! creates fun learning for all! Kahoot! is an innovative tool that all professors who are striving to be effective should put in their toolbox.

Keywords: effective teaching, effective teaching strategies, Kahoot!, digital devices, gaming technology
Eric Holt is CEO of Chiminus Enterprises, a diverse lifestyle marketing and consulting company that is nationally recognized. $\mathrm{He}$ is also the Managing Partner of Chiminus' successful subsidiary concert promotions company, The Lovenoise Group. Holt earned his Bachelor of

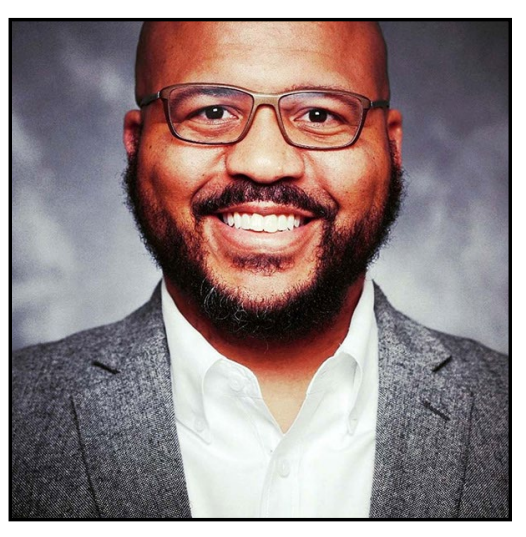
Science degree with a concentration in Communications from Howard University in Washington, D.C., and a J.D. from Nashville's Vanderbilt University Law School. Considered an expert in branding, marketing, and urban music, Holt is a regularly sought-after speaker at universities and business groups. He also consults within the entertainment industry and business leaders on promotion and branding strategy. Relentless in his pursuit of excellence which is complemented by his great work ethic, Holt insists on giving back to the community. He has proudly served as a board member on Nashville's Mayor Karl Deans' Music Business Council. Holt, also had the esteemed pleasure of serving as an Advisor and Diversity Committee Chair for Nashville chapter's National Academy of Recording Arts and Sciences (NARAS/Grammy's). He is also a member of the 30th class at Leadership Music. At the Curb College of Entertainment and Music Business at Belmont University he specializes in Urban Music, Live Music Venues, Marketing and Promotions.

Amy Bryson Smith, an alumna of Belmont University, is an Assistant Professor of Music Business. At Belmont, she has taught Copyright Law, Music Industry Contract Law, Business Law I, Business Law II, Intellectual Property Law, and Survey of Music Business. Mrs. Smith has prac- 


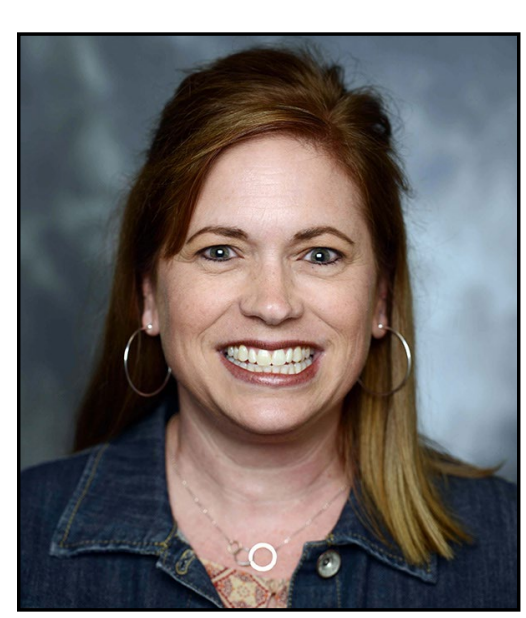

ticed law in Nashville since 1996. For many years, she was a partner of Chaffin, Burnsed, and Smith, PLLC (formerly Chernau, Chaffin \& Burnsed) where she practiced corporate law and represented a variety of individuals and companies in the music and entertainment business. She served as a litigator and transactional attorney, as well as a Rule 31 Mediator. Additionally, she was General Counsel of a national Christian non-profit corporation. She has also taught and served as Director of the Paralegal Studies Program at a local college. Mrs. Smith's published writings include: "Kiobel v. Royal Dutch Petroleum Co.: Radical Revision or Original Intent of the Alien Tort Statute," Southern Law Journal and "Arbitration: Trending in the Business and Legal World, But Is It Trending in your Business School?" Southern Journal of Business \& Ethics. Mrs. Smith serves on several boards, including secretary of the board of trustees of Donelson Christian Academy and Jeffrey Dean Ministries. 


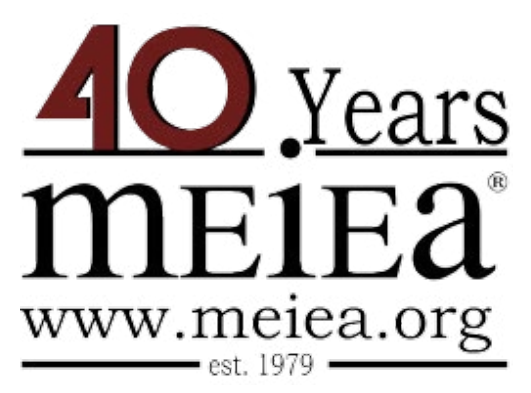

\section{PROCEEDINGS OF THE \\ 2019 INTERNATIONAL SUMMIT \\ OF THE \\ MUSIC \& ENTERTAINMENT \\ INDUSTRY EDUCATORS \\ ASSOCIATION}

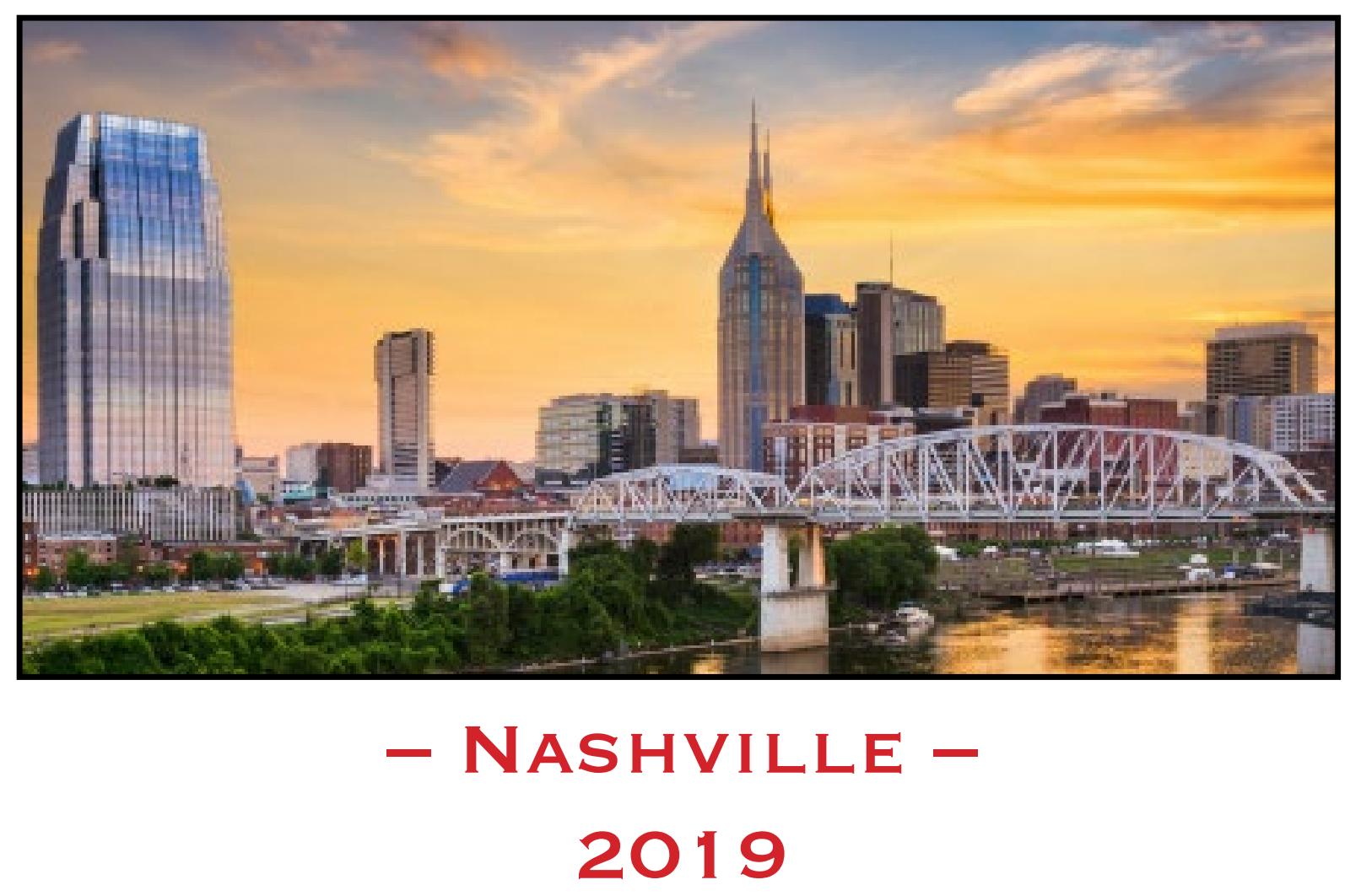

March 21 - 23, $2019 \cdot$ Belmont University - Nashville 